\title{
Op die voetspoor van Harold Henry Rowley (1890-1969)
}

\section{J J Spangenberg \\ Universiteit van Suid-Afrika}

\begin{abstract}
On the trail of Harold Henry Rowley (1890-1969)

$H H$ Rowley can be described as an enigmatic Old Testament scholar. Hailed as one of the leading Old Testament biblical theologians of the forties and fifties, he was also criticized for his 'middle-of-the-road' conclusions. This article takes a brief look at his academic career and biblical scholarship. It is argued that he is an exponent of the biblical theology movement in his attempts to reconcile the results of the historical-critical method with the traditional creeds of Christianity. Unfortunately he was not very successful because he did not regard the results of New Testament historical-critical research seriously. He was reluctant to admit that there was a difference between the historical Jesus and Christ as proclaimed by the church. Perhaps there are a few lessons to be learned from his timidity.
\end{abstract}

Only some of us can learn by other people's mistakes the rest of us have to be the other people.

\section{INLEIDING}

Terwyl die einde van die twintigste eeu al nader kruip, groei daar by my die behoefte om 'n keer terug te kyk en 'n bestekopname te doen van wat die afgelope eeu in die vak Ou Testament gedoen en bereik is. Hierdie behoefte bestaan klaarblyklik nie maar net by myself nie, maar ook by ander Ou-Testamentici. Die internasionale projek met die titel Hebrew Bible/Old Testament: The history of its interpretation (Saebø 1992) is onder andere 'n bewys hiervan en hier te lande kan 'n mens die RGN-navorsingsprojek wat onder leiding van Deist (1991) voltooi is en Le Roux se geskiedenis van die OTWSA (1993) ook vermeld.

Daar bestaan weliswaar reeds 'n aantal publikasies wat die groot navorsingslyne skets, bepaalde navorsingstendense identifiseer en van die belangrikste mylpale van die afgelope eeu bespreek (vgl Kraus 1982; Clements 1983; Knight \& Tucker 1985). Hierbenewens het daar ook al kleiner Forschungsgeschichten verskyn (vgl Haag, 
1985; Hermann 19901; Westermann 1990, 1991) asook ander publikasies waarin die bydraes van enkele Duitse Ou-Testamentici van hierdie eeu tot die vak belig word (vgl Crenshaw 1978, Smend 1989). Sulke publikasies oor Nederlandse, Franse, Italiaanse, Skandinawiese, Amerikaanse ${ }^{2}$, Britse ${ }^{3}$ en ander Ou-Testamentici van hierdie eeu is byna so skaars soos hoendertande. 'n Rede vir die skaarste aan publikasies oor ander Ou-Testamentici hang waarskynlik saam met die feit dat die Duitsers as die toonaangewers van die vak beskou word. Alhoewel dit so is dat Duitsland van die negentiende eeu as die bakermat van die kritiese navorsing van die $\mathrm{Ou}$ Testament beskou word (vgl Rogerson 1984), het Ou-Testamentici van ander lande in die twintigste eeu ook uitstaande bydraes gelewer. Na my mening kan dit die beoefening van ons vak net bevoordeel as daar uitvoeriger geskryf word oor hierdie Ou-Testamentici en die bydraes wat hulle gelewer het. Om dié rede het ek besluit om na die bydrae van Harold Henry Rowley (een van die leidende Britse Ou-Testamentici van hierdie eeu) te kyk.

\section{EERSTE KENNISMAKING}

In 'n artikel wat verlede jaar verskyn het, wys Prinsloo (1992:56) daarop dat die OuTestamentiese wetenskap in Suid-Afrika hoofsaaklik vanuit Holland en Duitsland gevoed is. My eerste kennismaking met Rowley was dan ook nie via die vak $\mathrm{Ou}$ Testament nie, maar via die vak Semitiese Tale terwyl ek besig was met navorsing vir 'n magister. Die verhandeling (Spangenberg 1979) het gehandel oor twee OuTestamentici (Gerhard von Rad en Hans Heinrich Schmid) se sienings rakende die Israelitiese wysheidsliteratuur en die Rowley-Festschrift (Noth \& Thomas 1955) het my gehelp om vertroud te raak met die sienings rakende die Israelitiese en ou Nabye Oosterse wysheidsliteratuur. Dié publikasie weerspieël die stand van navorsing rakende die wysheidsliteratuur tot en met 1955 en dit was vir my verrassend toe ek agterkom dat Rowley tot op daardie stadium (1955) niks oor die wysheidsliteratuur gepubliseer het nie. Na my mening was dit 'n goeie keuse van sy vriende en kollegas om 'n bundel artikels met die wysheid en wysheidsliteratuur as tema as 'n Festschrift aan hom op te dra. Deur middel van hierdie tema het hulle op 'n subtiele wyse gewys op 'n leemte in sy navorsing.

In die voorwoorde tot die Festschrift is 'n aantal dinge in verband met Rowley gesê wat my belangstelling in hom geprikkel het. Eerstens is daar gewys op die groot rol wat hy gespeel het om Britse en Europese Ou-Testamentici ná die Tweede Wêreldoorlog weer met mekaar in aanraking te bring. Die ieit dat verskillende Europese nasies aan hom lidmaatskap van hulle Akademies verleen en verskeie oorsese universiteite aan hom eregrade toegeken het (vgl Who was who 1961-1970), is 'n teken van die waardering wat daar bestaan het vir sy rol as brugbouer. 
Tweedens is daar hoë waardering uitgespreek vir sy kennis van die vak en sy weloorwoë standpunte oor sake waaroor hy hom uitgelaat het. Sy publikasies het gewoonlik omvangryke voetnote bevat. Noth het dit getipeer as 'bibliographische Fundgruben ersten Ranges' (Noth \& Thomas 1955:viii) ${ }^{4}$. Derdens is daar verwys na sy uitbouing en redigering van die 'Society for Old Testament study' se jaarlikse Book List. Rowley was vanaf 1946 'Book List Editor' en hy het dit dan ook omvorm tot die publikasies soos dit tans daar uitsien (Rogerson 1992:6).

Rowley se ywer om op hoogte te bly met navorsing op die terrein van die OuTestamentiese wetenskap het by my bewondering afgedwing toe ek in die Festschrift 'n lys van resensies wat hy geskryf het, gesien en verder ook sy resensie van Schmid se boek Wesen und Geschichte der Weisheit raakgeloop het (Rowley 1967b). Die begeerte om 'n keer indringend na sy werk te kyk, het metergaan gegroei - veral toe ek die volgende in die voorwoord van Garbini se boek History and ideology in ancient Israel (1988) te lese kry:

I remember with great effection Professor H H Rowley, who in the last years of his life was kind enough to send his books to the young Italian semitic scholar who had begun to recognize the problems of the Hebrew Bible through a valuable small book, The growth of the Old Testament, which saw the light in 1950 , the year in which that author entered university for the first time. For many years Professor H H Rowley has been an essential point of reference for me; later, I found refined tools for research in the writings of my friend Professor James Barr. In one sense I therefore feel myself to be a pupil of the best British biblical school, which has perhaps passed on to me something of its healthily empirical attitude.

(Garbini 1988:205)

\section{KORT LEWENSKETS 5}

Harold Henry Rowley is op 24 Maart 1890 in Leicester gebore as die vyfde van ses kinders. Na sy opleiding aan Wyggestonskool in Leicester is hy in 1910 na Bristol waar hy aan die 'Baptist College' en die Universiteit van Bristol in die Teologie studeer om in 1913 'n BA-Teologie te behaal. Gedurende hierdie jare was hy ook 'n eksterne student van die Universiteit van Londen en in 1912 het hy aan hierdie universiteit 'n BD-graad behaal. Hy ontvang in 1913 'n 'Dr Williams scholarship' wat hom in staat sou stel om in Europa verder te studeer. Voor sy vertrek lê hy eers die BD-Honneurseksamen in Hebreeus en Aramees aan die Universiteit van Londen af en word toe deur die uitbreek van die Eerste Wêreldoorlog verhinder om in Duitsland te gaan studeer. Hy studeer wel verder in Semitiese Tale aan die Univer- 
siteit van Oxford. In hierdie jare was G B Gray professor in 'Hebrew and Old Testament Exegesis', C F Burney was 'Oriel Professor of the Interpretation of Holy Scripture' en S R Driver was 'Regius Professor of Hebrew'. Hierdie manne het 'n bepaalde stempel op hom afgedruk. Van hulle het hy geleer om noukeurig met die tale van die Ou Testament om te gaan en om sy aandag op detail toe te spits. Moontlik was hulle ook indirek verantwoordelik vir sy aversie aan spekulatiewe filosofiese en teologiese redenasies.

Gedurende die Eerste Wêreldoorlog doen hy vir 'n kort tydjie oorlogsdiens in Egipte, maar moes vanweë slegte gesondheid na Brittanje terugkeer. Hy word toe in 1917 predikant van 'n 'United Baptist-Congregational' gemeente in Somerset. Hier tree hy op tot 1922 en vertrek in daardie jaar na China as 'n sendeling van die 'Baptist Missionary Society'. In China val die voorreg hom te beurt om as 'associate professor' in Ou Testament aangestel te word aan die 'Shantung Christian University'. Gedurende hierdie jare doen hy steeds navorsing in Semitiese tale en toe hy met langverlof na Brittanje terugkeer (1927-1928) voltooi hy 'n BLitt aan die Universiteit van Oxford. Die titel van sy tesis was: 'A comparison of the grammar and vocabulary of the Aramaic portions of the Old Testament with those of the Aramaic papyri and inscriptions.' Hierdie tesis is in 1929 gepubliseer onder die titel The Aramaic of the Old Testament: A grammatical and lexical study of its relations with other early Aramaic dialects.

Hy keer in 1929 na Brittanje terug ná 'n uitval met die 'Baptist Missionary Society' oor beleid en word kort na sy terugkeer aangestel as 'assistant lecturer' in Semitiese tale aan die Universiteitkollege van Suid-Wallis en Monmouthshire in Cardiff. (Theodore H Robinson het op hierdie tydstip die professoraat beklee.) In 1935 volg Rowley egter vir Edward Robertson op as professor in Semitiese tale aan die Universiteitkollege van Noord-Wallis in Bangor. Gedurende hierdie jare was hy onder andere ook dekaan van die 'Bangor School of Theology' (1936-1945) en viserektor van die kollege (1940-1945).

Gedurende 1945 volg Rowley weer vir Edward Robertson op, maar dié keer as professor in Semitiese tale en literatuur aan die Universiteit van Manchester. Dié leerstoel is in 1949 op aandrang van Rowley verander na professor in Hebreeuse taal en literatuur en dit het hy beklee tot en met sy aftrede in 1959. Sy jare aan die Universiteit van Manchester was van sy produktiefste en invloedrykste. Gedurende hierdie jare het hy onder andere diens gedoen as sekretaris verantwoordelik vir buitelandse korrespondensie van die 'Society for Old Testament Study' (1946-1960) en ook as dekaan van die Teologiese fakulteit (1953-1956). Kort na sy aftrede het hy verhuis na Stroud in Gloucestershire waar hy in 1969 oorlede is. 


\section{OORSIG OOR SY WERK}

Anderson (1972) en Eissfeldt (1970) gee elkeen in hulle huldeblyke 'n breë oorsig van Rowley se werksaamhede en publikasies en deur middel hiervan kan 'n mens baie gou ' $n$ idee kry van die omvang van sy werksaamheid en die breedheid van sy kennis.

Anderson (1972:313) onderskei drie fases in sy arbeid as Ou-Testamentikus. Gedurende die eerste fase het hy hom hoofsaaklik toegespits op Daniël en die apokaliptiese literatuur. Sy navorsing hieroor het neerslag gevind in drie boeke: The Aramaic of the Old Testament: A grammatical and lexical study of its relations with other early Aramaic dialects (1929), Darius the Mede and the four world empires in the book of Daniel: A historical study of contemporary theories (1935), en The relevance of apocalyptic: $A$ study of Jewish and Christian apocalypses from Daniel to the Revelation (1944a). In die tweede fase het hy sy aandag gerig op die vroeë geskiedenis van Israel. Hy het verskeie artikels gepubliseer oor Israel se verblyf in Egipte, die uittog, Moses en die monoteïsme, die vestiging in Kanaän en die verhouding tussen die Hebreërs en die Habiru/'Apiru. Sy standpunte hieroor het uiteindelik neerslag gevind in die Schweich-lesings van die Britse Akademie en wat gepubliseer is onder die titel From Joseph to Joshua: Biblical traditions in the light of archaeology (1950b). Gedurende die derde fase het hy hom hoofsaaklik met drie terreine besig gehou: (1) die Dooie Seerolle en (2) Ou-Testamentiese vraagstukke (histories, literêr en godsdienstig), en (3) Ou Testament teologie en godsdiensgeskiedenis. Van sy navorsing gedurende hierdie fase het hy gepubliseer in The servant of the Lord and other essays on the Old Testament (1952), From Moses to Qumran: Studies in the Old Testament (1963a) en Men of God: Studies in Old Testament history and prophecy (1963b), terwyl die boeke The unity of the Bible (1953), The faith of Israel: Aspects of Old Testament thought (1956) en Worship in ancient Israel: Its forms and meaning (1967) sy belangstelling in teologie en godsdiensgeskiedenis weerspieël. Gedurende die derde fase van sy arbeid het hy ook opgetree as redakteur of mede-redakteur van verskeie naslaanwerke en ander publikasies en het hy ook gedien op die paneel van vertalers van die Ou-Testamentiese gedeelte van die New English Bible (vgl Hunt 1970:80).

Eissfeldt (1970:84) periodiseer nie Rowley se arbeid nie, maar onderskei daarenteen ses terreine van die Ou-Testamentiese wetenskap waaroor hy nagevors en gepubliseer het. Die ses terreine is: (1) inleidingsvrae, (2) geskiedenis van Israel, (3) godsdiensgeskiedenis van Israel, (4) Ou Testament teologie, (5) vergelykende godsdienswetenskap, en (6) Qumrandokumente. Onder hierdie hoofde orden hy dan al Rowley se publikasies sonder sonder enige verdere bespreking. 


\section{WAARDEBEPALINGS VAN SY WERK}

Alhoewel die huldeblyke nie indringend na Rowley se vakmanskap kyk nie, beoordeel enkele van die skrywers wel sy werk en sy bydrae tot die Ou-Testamentiese wetenskap. Roberts (Rowley se opvolger in Bangor) sê in sy huldeblyk onder andere die volgende van hom:

His publications were never markedly original, but careful, thoroughly annoted and invariably safe. Sir Emrys Evans, I think, assessed him perfectly when he remarked to me that Rowley reminded him of a High Court Judge summing up a case, and students and specialists alike will always consult his works for full (and accurate!) details of the treatment of any Old Testament topic up to 1968.

(Roberts 1970:6)

Anderson maak 'n soortgelyke opmerking:

Rowley was at his best in the disentangling of complex critical problems where the proliferation of rival views had tended to obscure the essentials. His technical works were characterized by patient examination of all the available evidence, lucid presentation, balanced judgement, and formidable bibliographical documentation. It has sometimes been said that his works displayed no high degree of originality. There is some justice in this judgement. It is parhaps only in his reconstruction of the events of the Exodus and the Settlement that a stroke of genuine originality accompanies the comprehensive presentation of the evidence...

(Anderson 1972:316)

Die opmerking dat Rowley se navorsing mank gaan aan oorspronklikheid het ek telkens verneem op 'n onlangse studiercis in Brittanje (Mei 1933). Dit het my by tye ietwat ongemaklik gemaak en laat wonder: waarom navorsingstyd bestee om die bydrae te bepaal van 'n Ou-Testamentikus wat beskuldig word van onoorspronklikheid? Die feit dat Rowley se naam steeds in artikels en monografieë opduik (vgl o a Harrington 1973:260-265; De Geus 1976:44-47; Koch 1980:66-69; Davies, 1985:27; Auld 1986:26; Garbini 1988:205; Deist 1989:18; Hermann 1990:66), het my egter aangespoor om met die ondersoek voort te gaan - veral ook omdat Childs (1970:24) hom tipeer as 'the leading Old Testament Biblical theologian' van die veertiger en vyftigerjare in Brittanje, en Baker (1976:343) die volgende van Rowley en Dodd sê: Their work is an important part of the foundation of modern biblical scholarship in this country [Britain] ...' 


\section{EKSPONENT VAN DIE BYBELSE TEOLOGIE BEWEGING}

Om prominente wetenskaplikes se werk en bydrae tot hulle vak te kan bepaal, is dit noodsaaklik om hulle wetenskaplike milieu en historiese konteks in ag te neem. Mense is nou maar eenmaal kinders van hulle tyd en niemand van ons kan die invloede van die milieu en die tyd waarin ons leef, ontsnap nie. Rowley is hierop geen uitsondering nie. Hy het nie alleen geleef in die jare toe die Bybelse teologie in sy Noord-Amerikaanse baadjie 'n hoogtepunt (1940-1960) beleef het nie (vgl Childs, 1970:14, 85; Morgan 1990:88), maar ook toe die Bybelse argeologie sy bloeitydperk (1925-1948) beleef het (vgl Moorey 1991:54).

Die opkoms van die Bybelse teologie in Noord-Amerika het verband gehou met 'n poging om uit die impasse te kom waarin die stryd tussen die liberale en konserwatiewe teologieë dáár te lande gekom het. Die voorstanders van hierdie vorm van teologie wou erns maak met die resultate van die histories-kritiese Bybelnavorsing, maar wou tegelykertyd ook vashou aan die tradisionele Christelike belydenisse. 'One was offered the possibility of accepting Biblical criticism without reservation as a valid tool while at the same time recovering a robust, confessionally oriented theology' (Childs 1970:21). Rowley se teologiese publikasies The relevance of the Bible (1942), The re-discovery of the Old Testament (1946) en The unity of the Bible (1953) het standpunte verwoord wat aangesluit het by die beskouings van diegene wat dié soort teologie voorgestaan het.

Rowley kan tereg as 'n eksponent van hierdie teologiese rigting beskou word. Die sake wat in die Bybelse Teologie vooropstaan en wat ook in sy werke weerklank gevind het, is (1) die relevansie van die Bybel, (2) die inspirasie van die Bybel, (3) die eenheid van die Bybel, en (4) Bybelse argeologie en openbaring in die geskiedenis. Ek bespreek elkeen van hierdie sake kortliks alvorens ek 'n aantal kritiese opmerking oor sy werk en bydrae tot die Ou-Testamentiese wetenskap maak.

\subsection{Die relevansie van die Bybel}

Volgens Rowley is die Bybel relevant vir ons tyd. Dit is nie maar net ' $n$ versameling van antieke geskrifte nie - God het 'n hand gehad in die totstandkoming daarvan. Daar is ' $n$ religieuse dimensie verbonde daaraan en as mense hulleself maar net wil instem, sal hulle die openbaring ontvang wat via die Bybel bemiddel word. Bybelstudie kan mense hierin help, want deur Bybelstudie kan jy jouself verplaas in die tyd toe 'n bepaalde Bybelboek geskryf is; kan jy jouself indink in daardie tyd en die impak ervaar wat die woorde op hulle eerste hoorders gehad het (Rowley 1942:13). S6 kom 'n mens dan agter wat God se wil is vir jou lewensomstandighede en die tyd waarin jy leef. Bybelse argeologie kan Bybelstudente voorts help om die brug te slaan tussen die tyd waarin hulle leef en die tyd waarin die eerste hoorders geleef 
het. Vir Rowley is dit baie belangrik dat die lesers van die Bybel ' $n$ historiese bewussyn moet hê (vgl Rowley 1953:29). Volgens hom kan die Bybel slegs reg verstaan word wanneer bepaalde stellinge en uitsprake daarin histories geplaas en teen die agtergrond van 'n bepaalde tyd geïnterpreteer word. Dit is dan ook die taak van Bybelse argeologie om mense te help met die rekonstruksie van die tyd en die omstandighede van die gebeure wat in die Bybel vermeld word - nie om die historisiteit van gebeure wat in die Bybel vermeld word, te bewys nie (Rowley 1942:14-15).

\subsection{Die inspirasie van die Bybel}

Rowley (1942:24) stel dit onomwonde dat die Bybel vir hom die Woord van God is en nie maar net die Woord van God bevat nie. Hiermee bedoel hy nie dat die Bybel van voor tot agter die direkte woorde van God weergee nie, maar dat dit iets van God se karakter openbaar. Omdat die skrywers van die Bybelboeke geïnspireerde mense was, kon God se woord (sy karakter) via hulle persoonlikhede aan ons geopenbaar word. 'The Word of God is mediated to us through the instrument of their personality. God, being personal, cannot adequately reveal Himself save through personality, and can only reveal Himself perfectly in perfect personality' (Rowley 1940:165-166). Jesus is hierdie perfekte persoonlikheid en daarom is Hy ook die perfekte woord van God. In Hom behoort dit vir ons klinkklaar te wees hoe en wie God is.

Wanneer 'n mens nou die Ou Testament lees en daar verhale vind wat aanstootlik is en wat 'n God aan ons voorhou wat onmenslik wreed is (vgl die verhaal van Ussa en die ark [2 Sam 6] en die verhaal van die die ophang van die sewe seuns uit die nageslag van Saul om 'n hongersnood in Israel te verbreek [2 Sam 21]), moet ons besef dat ons met gebrekkige persoonlikhede te doen het. Mense het in die OuTestamentiese tye só oor God gedink, maar dit is nie die ware beeld van God nie (Rowley 1940:167-170; 1942:28-32). Die ware beeld van God vind ons in Jesus Christus en daarom moet ons, wanneer ons die Ou Testament lees, telkens onsself afvra of dit wat ons aangaande God wys word werklik strook met dit wat ons van Hom in Jesus Christus weet. 'All that we learn of God in the Old Testament that is in harmony with the revelation given in Christ is truly of God....And all that we learn of God in the Old Testament that is not in harmony with the revelation given in Christ is not of God' (Rowley 1940:170; 1942:33).

Die inspirasie waarborg dus nie dat die Bybel foutloos en sonder teenstrydighede is nie. Alles in die Bybel staan ook nie op dieselfde vlak nie. Daar was 'n voortgang in die openbaring en met hierdie voortgang moet ons rekening hou wanneer ons die Bybel lees (Rowley 1940:171; 1942:34). 


\subsection{Die eenheid van die Bybel}

'n Saak wat Rowley na aan die hart gelê het en wat duidelik sy aangetrokkenheid tot die Noord-Amerikaanse vorm van Bybelse teologie bewys, is die eenheid van die Bybel. Hierdie eenheid fundeer hy in die eerste plek in die openbaring van God. 'If God was revealing Himself, then there should be some unity about the revelation, since it was the same Being Who was being revealed' (Rowley 1953:8). Volgens hom is die Bybel nie maar net 'n weergawe van die nadenke van Israel en die vroeë Christelike kerk nie - dit is die weergawe van God se openbaring (Rowley 1953:15). Hierdie openbaring het in die geskiedenis plaasgevind en daarom moet ons 'n historiese bewussyn aankweek sodat ons dit wat ons lees teen die regte agtergrond kan lees en verstaan. Omdat die openbaring in die geskiedenis plaasgevind het, moet ons ook rekening hou met 'n voortgang van die openbaring (Rowley 1940:171; 1945: 15; 1953:15).

Wanneer hy oor God se openbaring en die Ou Testament skryf, beklemtoon hy die rol wat Moses as openbaringsmiddelaar gespeel het. Volgens hom kan byna elke kreatiewe idee wat in die Ou Testament te vinde is, teruggevoer word na die godsdienstige idees wat via Moses aan Israel bemiddel is (Rowley 1953:21). Hy is selfs van mening dat die Dekaloog na Moses teruggevoer kan word. Moses het ook die basis gelê van die etiese monoteïsme wat as dié kenmerk van die Israelitiese godsdiens beskryf kan word (Rowley 1953:21, 25). Ander elemente van Israel se godsdiens, soos sy verkiesing deur God en dat hy 'n missionêre plig teenoor ander volke het, kan teruggevoer word na Moses en die uittoggebeure (Rowley 1953:26). Daar is egter een profeet, naamlik Deutero-Jesaja, wat besonder beslag gegee het aan hierdie elemente van die Israelitiese godsdiens. 'The prophet who was above all others the prophet of monotheism was also the prophet of universalism and of the mission of Israel' (Rowley 1953:28). Deur middel van Deutero-Jesaja se verkondiging aangaande die kneg van die Here slaan Rowley die brug tussen die Ou en die Nuwe Testament, want Jesus Christus sou dan die taak van die kneg (wat niks anders was as die taak van Israel nie) volmaak vervul (Rowley 1953:60).

Afgesien van hierdie lyn (monoteïsme, die etiese eise, verkiesing, missionêre plig) wat volgens Rowley deur die Bybel loop, is daar nog ander bewyse dat die twee testamente uit een mond praat. Een hiervan is dit wat die Bybel aangaande God en die mens leer. Soos in die vorige geval beklemtoon hy weer dat beide testamente één God verkondig en dat hierdie God beeldloos voorgestel word (Rowley 1953:6364). Tweedens dat hierdie God Hom in die geskiedenis en ervaring openbaar: 'Underlying the whole thought of the Bible is the idea of a God Who reveals Himself in history and experience' (Rowley 1953:65). Ten nouste hiermee hang saam die gedagte van belofte en vervulling. God se handelinge in die geskiedenis kan egter nie uit enige gebeurtenis afgelei word nie. Die openbaring wat deur die geskiedenis kom, moet voorafgegaan word deur 'n belofte. Die gebeurtenis moet dan ook deur 
'n geloofwaardige persoon geïnterpreteer word. Rowley formuleer dit so: 'We have first the announcement of the significant fact of the history through a prophetic person, speaking in the name of God, then the fulfilment of the announcement, and finally the interpretation of the event by one whose credentials were supplied by the fulfilment' (Rowley 1953:66). As voorbeeld verwys hy na die uittoggebeure. Die openbaring is nie slegs te vind in die gebeurtenis nie, maar ook in Moses se woorde wat dit begelei het. 'His prophetic word and the fulfilment in history dovetailed into one another,..' (Rowley 1953:66). In hierdie gebeurtenis en die profetiese woord wat dit begelei het, word iets van God se karakter geopenbaar. Dit word duidelik dat Hy ' $\mathrm{n}$ betroubare, genadige, medelydende, verkiesende en reddende God is (Rowley 1953:66-69).

Aangaande die mens leer die Bybel dat hy deur God geskep is om aan Hom gehoorsaam te wees en in gemeenskap met Hom te leef. 'Granting all the difference of level that there are to be found within the Bible, it is characteristic of its thought as a whole that a man is a creature capable of enjoying the fellowship of God and made to serve Him, and that these two belong together' (Rowley 1953:77). Ten nouste hiermee hang dan ook die gedagte saam van verkiesing en diens. Sowel Israel as die kerk is deur God verkies, maar hierdie verkiesing loop hand aan hand met diens (Rowley 1953:78).

Die kwessie van die vervulling van beloftes is vir Rowley 'n verdere aspek wat die eenheid van die twee testamente bewys. Volgens hom kyk die Ou Testament voortdurend vooruit na iets wat buite dit lê. Hierdie 'iets' is nie die post-Bybelse Judaïsme nie. Hy formuleer dit so: 'While post-Biblical Judaism is completely unintelligible without the Old Testament, however, it is not the case that the Old Testament is unintelligible without post-Biblical Judaism, whereas it is claimed that the Old Testament is not fully intelligible without the New Testament. For if the New Testament looks back to the Old which preceded it, the Old looks forward to something which should follow it, and that something is not post-Biblical Judaism' (Rowley 1953:94). In die Ou Testament is daar die hoop van 'n blink toekoms ('Golden Age') waarin mense van verskillende rasse die God van Israel sal aanbid, sy wet sal aanvaar en hulle aan die toekomstige koning uit die geslag van Dawid sal onderwerp (vgl ook Rowley 1945:184-201). Volgens hom word hierdie beloftes nie vervul in die Judaïsme nie, maar in die Christendom (Rowley 1953:95). In Jesus Christus openbaar God Homself weer deur 'n persoon (soos in die geval met Moses). Hierdie Persoon se aansprake en uitsprake word (net soos in die geval met Moses) vervul in die geskiedenis. Die openbaringsmedium is dus dieselfde: 'prophetic personality [and] historical events' (Rowley 1953:97). Jesus se aansprake en uitsprake sluit egter ten nouste aan by Deutero-Jesaja se verkondiging aangaande die kneg van die Here soos dit veral in die vierde kneglied (Jes 52:13-53:12) tot uitdrukking kom. 'It is quite clear that our Lord was much influenced by this 
passage, and thought of His death before it took place in terms of the death of the Servant' (Rowley 1953:104-105). Hy het dus die profetiese woord vervul en daardeur ook'n einde gebring aan die Ou-Testamentiese offerdiens. '[S]acrifice was suspended because it had been superseded by a sacrifice which corresponded to one promised in the Old Testament and achieved in history in a setting which bore the signature of God no less clearly than the earlier revelation in the Mosaic period' (Rowley 1953:107-108).

\subsection{Bybelse argeologie en openbaring in die geskiedenis}

Die beklemtoning van openbaring deur die geskiedenis is een van dié kenmerke van die Noord-Amerikaanse vorm van Bybelse teologie. 'n Ander kenmerk wat ten nouste hiermee saamhang, is die beklemtoning van die resultate van Bybelse argeologie. Childs (1970:42) som die samehang tussen hierdie twee mooi op met die volgende stellings: 'God has revealed himself in the real events of human life which are found in the Bible. The theologian who seeks this knowledge of God must therefore study history. Since archaeology is the best tool for the study of ancient history, Biblical theology and Biblical archaeology belong together'.

Dat Rowley homself tuis gevoel het in hierdie teologiese dampkring, is duidelik uit sy beklemtoning van die feit dat God hom in sowel indiwiduele as korporatiewe ervarings (geskiedkundige gebeure) openbaar het (1945:136). Hy lê voorts klem daarop dat nie alle gebeure 'n openbaring van God se karakter is nie. 'n Gebeurtenis moet begelei word deur 'n profetiese woord om daarvan 'n openbaring te kan maak (Rowley 1953:66). Hy het ook 'n geweldige voorliefde vir die resultate van Bybelse argeologie gehad en dit is nie vreemd nie dat hy heelwat energie bestee het om argeologiese data wat lig kan werp op die uittog-en intoggebeure te versamel (vgl Rowley 1950b), want hier lê (volgens hom) die wortels van Israel se monoteisme en dit wat hulle verder aangaande God geglo het. In hierdie gebeure (soos geïnterpreteer deur die geïnspireerde Moses) is 'n hele aantal karaktereienskappe van God geopenbaar.

\section{SWAK PLEKKE IN ROWLEY SE TEOLOGIESE DENKE EN ARBEID}

\subsection{Die verhouding geloof en wetenskap}

Rowley se publikasies sou ek in twee kategorieë wou verdeel: (1) die publikasies waarin hy Ou-Testamentiese inleidingsvraagstukke, historiese vraagstukke en vraagstukke wat op die terrein van die Semitiese tale lê, behandel en (2) publikasies waarin hy as Christen Ou-Testamentiese temas wat vir protestantse Christene van belang sou wees, hanteer. 
In die voorafgaande gedeelte het ek hoofsaaklik aandag gegee aan die tweede groep van publikasies. Op grond van hierdie publikasies sou 'n mens kon sê dat ons hier met 'n redelik behoudende Ou-Testamentikus te doen het. Die tradisionele Christelike belydenisse was vir hom belangrik en binne die grense van hierdie belydenisse wou hy dan ook sy vakmanskap bedryf. Na my mening het hy egter nie altyd goed onderskei tussen geloof en wetenskap nie. Ek wys op enkele voorbeelde in sy publikasies.

Rowley tref nie 'n onderskeid tussen Jesus as historiese persoon en die kerk se belydenis dat hy die Christus was nie en maak op grond hiervan uitsprake wat bevraagteken kan word. In sy boek The unity of the Bibel sê hy onder andere die volgende: 'In the New Testament we find that our Lord appears before men with claims and promises. To examine them all is unnecessary. Suffice is to say that $\mathrm{He}$ believed that His work was of wide and enduring importance to men, and that His death would be of unique significance and power' (Rowley 1953:97). Vergelyk ook die volgende stelling: 'It has been said that Jesus, Who believed Himself to be the Messiah, also believed that His death would achieve what the death of the Servant was expected to achieve...' (Rowley 1953:112). Op 'n ander plek waar hy oor Jesaja 53 skryf, sê hy: 'It is quite clear that our Lord was much influenced by this passage, and thought of His death before it took place in terms of the death of the Servant.' (Al die bostaande beklemtonings het ek gedoen.) 'n Mens kan onmiddellik vra: Hoe weet Rowley al hierdie dinge anders as op grond van sy geloof? Hierdie stellings oor wat Jesus sou geglo en gedink het, is nie histories verifieerbaar nie. Nuwe Testamentici van sy dag het al die standpunt ingeneem dat ons in die evangelies met die kerk se interpretasies van Jesus se leer en lewe te doen het. Rowley was wel op hoogte hiervan, maar nie bereid om hierdie geleerdes se sienings ernstig op te neem nie. In 'n voetnoot (Rowley 1953:108-109) spreek hy byvoorbeeld kritiek op F C Grant uit: 'F.C. Grant holds that the identification of Jesus in the Gospels with the Son of Man, the Son of David, and the Suffering Servant offers evidence of the reflection of more than one type of Christology in the Early Church, and cannot derive from the "messianic consciousness" of Jesus, since they are incompatible concepts (An Introduction to New Testament Thought, 1950 pp.22 ff).' Volgens Rowley is dit moontlik dit Jesus self hierdie konsepte verenig het. 'There is...no reason why they could not have come together in His mind' (Rowley 1953:109). Hier is nie 'n Ou-Testamentikus aan die woord nie - ook nie 'n Nuwe-Testamentikus nie, maar 'n dogmatikus!

Rowley was dus bereid om die resultate van die historiese kritiek ten opsigte van die Ou Testament te aanvaar, maar hy was nie bereid om die resultate van die historiese kritiek ten opsigte van die Nuwe Testament te aanvaar wanneer dit die 
tradisionele Christelike belydenisse aangaande Jesus in die gedrang bring nie. Dit wat die Christelike kerk aangaande Jesus bely het, het vir hom vasgestaan en dit wat hy as Ou-Testamentikus geskryf het, moes hierdie belydenisse ondersteun ${ }^{6}$.

\subsection{Openbaring van God of nadenke oor Hom?}

$\mathrm{Na}$ my mening kan 'n mens nie die resultate van die historiese kritiek aanvaar en terselfdertyd 'n verouderde Skrifbeskouing huldig nie. Die resultate van die historiese kritiek vereis 'n ander Skrifbeskouing (vgl Spangenberg 1993:128). Die idee dat daar 'n voortgang in die openbaring van God was en dat die Bybel die verhaal vertel van hierdie voortgang, is al 'n stap in die regte rigting (vgl Rogerson 1982). Rowley het hierdie idee aangehang, maar terselfdertyd ook ietwat verder gegaan en die mens se belewing en verwerking van die openbaring beklemtoon. Hierdie openheid om die menslike aandeel te erken, het hom in staat gestel om moeilike gedeeltes soos die twee voorbeelde van Ussa en die ark, en die ophang van die sewe seuns uit Saul se nageslag (vgl 6.2 hierbo), met sy siening van die openbaring sinvol te kon verduidelik (vgl Rowley 1940:167-170; 1945:132). Die vraag bly egter by 'n mens spook: Is dit werklik so dat hierdie mense die openbaring misverstaan en swak gereflekteer het? Was hulle werklik onvolmaakte persoonlikhede? Is dit nie beter om te sê dat ons in die Bybel met voortgesette nadenke oor God te doen het nie? As Jesus 'n volmaakte persoonlikheid gehad het en God se openbaring volmaak gereflekteer het, beteken dit nog glad nie dat daardie volmaakte openbaring ons onbevlek bereik nie, want ons hoor alleen maar daarvan via die onvolmaakte evangelieskrywers. Na my mening was Rowley op die regte spoor met die volgende stelling: '[The Bible] is the record of man's growing experience of God, and progressive response to God' (1942:35). Dit is net jammer dat hy nie bereid was om nog meer waagmoed aan die dag te lê in sy beskrywing van hoe die Bybelboeke tot stand gekom het nie.

\subsection{Gebrek aan oorspronklikheid en diepgang}

Wanneer 'n mens Rowley se tweede groep van publikasies lees, kan jy verstaan waarom sommige geleerdes hom beskuldig van onoorspronklikheid (vgl o a Roberts 1970:6). Hy het 'n voorliefde gehad vir sekere temas en hierdie temas het tot vervelens toe in sy publikasies opgeduik. Die temas is: die eksodusgebeure en Israel se verkiesing, Moses en monoteïsme, die dekaloog en verbondsluiting by Sinai, die vestiging in Kanaän (in twee fases), die missionêre plig van Israel, en Deutero-Jesaja en die kneg van die Here. Hierdie publikasies (as 'n mens hulle in 'n kronologiese volgorde lees), weerspieël geensins 'n ontwikkeling in sy denke nie. Telkens lees ' $n$ mens maar net 'much more of the same'. 
Die breedheid van sy kennis en sy weloorwoë menings word wel geïllustreer deur die publikasies wat onder die eerste groep val, naamlik Ou-Testamentiese inleidingsvraagstukke, historiese vraagstukke en vraagstukke wat op die terrein van die Semitiese tale lê (vgl Rowley 1952, 1963a, 1963b). Dit is dan ook hoofsaaklik hierdie publikasies wat tans nog aangehaal word wanneer geleerdes sekere onderwerpe bespreek wat hy ook aangeroer het.

\section{SLOT: OP DIE BREUKLYN}

Rowley het geleef en werk tussen twee belangrike gebeure op die terrein van die Bybelwetenskappe in Brittanje. Die eerste hou verband met die publikasie van Benjamin Jowett se artikel 'On the interpretation of Scripture'7 in Essays and Reviews gedurende 1860 en die tweede met die publikasie van James Barr se boek The Bible in the modern world in 1973. Hierdie twee publikasies het gelei tot 'n paradigmaverandering op die terrein van die Bybelwetenskappe. Rowley se publikasies gee nie blyke daarvan dat hy kennis geneem het van Jowett se sienings en dat hy daarmee geworstel het nie. Barr (Rowley se opvolger in Manchester) het die drade wat Jowett neergegooi het, weer opgeneem en die Bybelwetenskappe gekonfronteer met die vraag: Hoe lees en verstaan 'n mens die Bybel in die twintigste eeu? Hier te lande is die paradigmaverandering ingelei met wyle professor Willem Vorster se intreerede 'n Ou Boek in 'n nuwe wêreld (1977). Hierdie paradigmaverandering stel geweldige eise aan die teologiese wetenskap en die Suid-Afrikaanse Ou-Testamentici sal hulle moet afvra of hulle soos Rowley gaan terugdeins en poog om met die verouderde idee van 'n voortgaande openbaring gaan bly werk en of hulle met 'n nuwe gedagte na vore gaan kom. Na my mening kan ons nie meer soos Rowley weier om die pad van die historiese kritiek einduit te loop nie. Ons sal ons Nuwe-Testamentiese kollegas ernstig moet opneem en moet aanvaar dat daar 'n verskil is tussen die historiese Jesus en die Christus van die kerk se belydenis ${ }^{8}$.

\section{ENDNOTAS}

1. Nie al die bundels in die reeks Enräge der Forschung bevat 'n historiese navorsingsoorsig nie.

2. Daar bestaan wel 'n publikasie oor die Amerikaner W F Albright (vgl Van Beek 1989).

3. R E Clements het 'n boek geskryf oor vier Britse Ou-Testamentici wat tot die Baptiste tradisie behoort het ( $\mathrm{T}$ H Robinson, $\mathrm{H}$ W Robinson, $\mathrm{H} \mathrm{H}$ Rowley en A $\mathrm{R}$ Johnson). Die uitgewery met wie hy aanvanklik onderhandel het, het later besluit om kop uit te trek en die boek het gevolglik nie die lig gesien nie. Professor Clements was gewillig om 'n kopie van die gedeelte wat hy oor Rowley geskryf het ('The biblical scholarship of Harold Henry Rowley') aan my te verskaf. 
4. As jong MA-student was ek beïndruk deur die magdom voetnote wat Rowley se publikasies gewoonlik 'versier' het. Ek was ook gou hierna van mening dat 'n akademikus se erudisie uit die bibliografieë blyk wat die onderbou van sy publikasies weerspieël. Eers tydens my doktorale studiejare het ek ingesien dat 'n akademikus nie sy hand op alle publikasies kan en hoef te lê nie. Dit gaan immers nie om die aantal gespreksgenote wat jy in jou argument kan betrek nie, maar om die statuur van die gespreksgenote wat jy betrek en om die kwaliteit van jou argumentvoering. Voorts behoort elke wetenskaplike publikasie van kreatiwiteit te getuig.

5. Inligting hieroor het ek verkry uit Eissfeldt (1970), Roberts (1970), Anderson (1972), Who was who 1961-1970, en uit die ongepubliseerde geskrif van Clements vermeld in nota 3.

6. In die lig hiervan kan 'n mens ook Rowley se optrede teenoor sy kollega John Allegro verstaan. Hy het aanbeveel dat sy aanstelling aan die Universiteit van Manchester nie hernu moes word nie, want Allegro het vreemde idees oor die oorsprong van die Christendom begin verkondig na aanleiding van sy bestudering van die Dooie Seerolle. (Hierdie idees is uiteindelik gepubliseer in sy boek The sacred mushroom and the cross: $A$ study of the nature and origins of Christianity within the fertility cults of the ancient Near East [1970].) Rowley het egter nie sy sin gekry nie, want kollegas van ander departemente het besef dat hier meer op die spel was. Rowley het hieroor gebelgd gevoel en hom dit persoonlik aangetrek dat hulle hom 'in die steek gelaat het'. (Hierdie inligting het ek verkry tydens my oorsese besoek en in die ongepubliseerde geskrif vermeld in nota 3.)

7. Benjamin Jowett was professor in Grieks verbonde aan die Universiteit van Oxford. Sy stelling dat die Bybel soos enige ander literêre werk gelees moet word, was mede-verantwoordelik vir die storm wat losgebreek het na die publikasie van die versamelbundel Essays and Reviews onder redaksie van $\mathrm{H}$ B Wilson (vgl Ellis 1990). Daar is 'n duidelike ooreenkoms tussen hierdie storm en die een wat losgebreek het na wyle professor Willem Vorster se intreerede oor die interpretasie van die Nuwe Testament (vgl Vorster 1977). Sy oproep dat die Bybel soos enige ander literêre werk gelees moet word, is as 't ware 'n herhaling van Benjamin Jowett se oproep.

8. 'n Woord van dank aan my kollega Willem Boshoff vir sy rol as 'vroedvrou' by die geboorte van hierdie artikel. 
Literatuurverwysings

Allegro, J M [1970]. The sacred mushroom and the cross: A study of the nature and origins of Christianity within the fertility cults of the ancient Near East. London: Hodder \& Stoughton.

Anderson, G W 1972. Harold Henry Rowley 1890-1969, in Proceedings of the British Academy 1970, vol 56, 309-319. London: Oxford University Press.

Auld, A G 1986. Amos. Sheffield: JSOT Press. (Old Testament Guides.)

Baker, D L 1976. Two Testaments, one Bible. Leicester: Intervarsity.

Barr, J 1973. The Bible in the modem world. London: SCM.

Childs, B S 1970. Biblical Theology in crisis. Philadelphia: Westminster.

Clements, R E 1983. A century of Old Testament study. Rev ed. Guildford: Lutterworth.

Crenshaw, J L 1978. Gerhard von Rad. Waco: Word Books. (Makers of the modern theological mind.)

Davies, P R 1985. Daniel. Sheffield: JSOT Press. (Old Testament Guides.)

De Geus, C H J 1976. The tribes of Israel: An investigation into some of the presuppositions of Martin Noth's amphictyony hypothesis. Assen: van Gorcum. (Studia Semitica Neerlandica 18.)

Deist, F E 1989. The prophets: are we heading for a paradigm switch? in Fritz, V, Pohlmann, K-F \& Schmitt, H-C (Hrsg) Prophet und Prophetenbuch: Festschrift für Otto Kaiser zum 65. Geburtstag, 1-18. Berlin: De Gruyter. (BZAW 185).

- [1991]. Wetenskapsteorie en vakmetodologie in Bybelwetenskaplike navorsing in Suid-Afrika: 'n wetenskapsteoretiese en sosiaal-historiese studie, 3 volumes. RGN-verslag, Pretoria.

Eissfeldt, O 1970. Harold Henry Rowley (1890-1969): ein Herold weltweiter Wissenschaft vom Alten Testament. $T h L Z$ 95, 81-87.

Ellis, I 1990. Essays and Reviews, in Coggins, R J \& Houlden, J L (eds) A dictionary of biblical interpretation, 203-204. London: SCM.

Garbini, G 1988. History and ideology in ancient Israel. London: SCM.

Haag, H 1985. Der Gottesknecht bei Deuterojesaja. Darmstadt: WBG. (Erträge der Forschung 233.)

Harrington, W J 1973. The path of Biblical Theology. Dublin: Gill \& Macmillan.

Hermann, S 1990. Jeremia: der Prophet und das Buch. Darmstadt: WBG. (Erträge der Forschung 271.)

Hunt, G 1970. About the New English Bible. London: Oxford University Press.

Jones, R T 1972. Theology in Bangor: 1922-1972. Bangor: University of Wales Press. 
Jowett, B 1860. On the interpretation of Scripture, in Wilson, H B (ed) Essays and Reviews, 330-433. London: John W Parker \& son.

Knight, D a \& Tucker, G M (eds) 1985. The Hebrew Bible and its modern interpreters. Philadelphia: Fortress. (The Bible and its modern interpreters 1.)

Koch, K 1980. Das Buch Daniel. Darmstadt: WBG. (Erträge der Forschung 144.)

Kraus, H-J 1982. Geschichte der historisch-kritischen Erforschung des Alten Testaments. 3.Aufl. Neukirchen-Vluyn: Neukirchener Verlag.

Le Roux, J H 1993. The story of two ways: Thinty years of Old Testament scholarship in South Africa Pretoria: Verba Vitae. (Old Testament Essays: Supplement series no 2.)

Moorey, $\mathbf{R}$ 1991. A century of Biblical Archaeology. Cambridge: Lutterworth.

Morgan, R 1990. Biblical Theology, in Coggins, R J \& Houlden, J L (eds) A dictionary of biblical interpretation, 86-89. London: SCM.

Noth, M \& Thomas, D W (eds) 1955. Wisdom in Israel and in the ancient Near East: Presented to Professor Harold Henry Rowley. Leiden: Brill. (VTS 3.)

Prinsloo, W S 1992. Perspektiewe op die stand van die Ou-Testamentiese wetenskap in Groot Brittanje. Skrif en Kerk 13, 56-64.

Roberts, B J 1970. Obituary: Harold Henry Rowley. University College of North Wales, Bangor Gazette Jan, vol 9, p 6.

Rogerson, J W 1982. Progressive revelation: its history and its value as a key to Old Testament interpretation. EpRe 9, 73-86.

- 1984. Old Testament criticism in the nineteenth century: England and Germany. London: SPCK.

- 1992. The Society for Old Testament Study: A short history 1917-1992. Leeds: Maney \& son.

Rowley, H H 1929. The Aramaic of the Old Testament: A grammatical and lexical study of its relations with other early Aramaic dialects. Oxford: Oxford University Press.

- 1935. Darius the Mede and the four world empires in the book of Daniel: $A$ historical study of contemporary theories. Cardiff: University of Wales Press.

- 1940. The inspiration of the Old Testament, $C Q 18,164-177$.

— 1942. The relevance of the Bible. London: James Clarke.

- 1944a. The relevance of apocalyptic: $A$ study of Jewish and Christian apocalypses from Daniel to the Revelation. London: Lutterworth.

- 1944b. The missionary message of the Old Testament. London: Carey Kingsgate.

— 1946. The re-discovery of the Old Testament. London: James Clarke. (Library of contemporary theology.) 
Rowley, H H 1950a. The growth of the Old Testament. London: Hutchinson.

- 1950b. From Joseph to Joshua: Biblical traditions in the light of archaeology. London: Oxford University Press.

- 1952. The servant of the Lord and other esscays on the Old Testament. Oxford: Basil Blackwell.

- 1953. The unity of the Bible. London: Carey Kingsgate.

- 1956. The faith of Israel: Aspects of Old Testament thought. London: SCM.

— 1963a. From Moses to Qumran: Studies in the Old Testament. London: Lutterworth.

- 1963b. Men of God: Studies in Old Testament history and prophecy. London: Thomas Nelson \& sons.

- 1967a. Worship in ancient Israel: Its forms and meaning. London: SPCK.

— 1967b. Review: H H Schmid 1966. Wesen und Geschichte der Weisheit. Berlin: Töpelmann. (BZAW 101), in ET 79, 6.

Saebø, M 1992. Hebrew Bible/Old Testament: The history of its interpretation. Report on a new international project. Bib. 73, 137-143.

Scholder, K 1990. The birth of modern critical theology: origins and problems of biblical criticism in the seventeenth century. London: SCM.

Smend, R 1989. Deutsche Alttestamentler in drei Jahrhunderten. Göttingen: Vandenhoeck \& Ruprecht.

Spangenberg, I J J 1979. 'n Kritiese beoordeling van die kritiek van H H Schmid op Gerhard von Rad ten opsigte van die wysheidsliteratuur. MA-verhandeling, Universiteit van Stellenbosch.

- 1993. Galileo Galilei en die boek Prediker: 'n Les uit die kerkgeskiedenis. ThEv 26/2, 121-131.

Van Beek, G W 1989. The scholarship of William Foxwell Albright: An appraisal. Atlanta: Scholars. (Harvard Semitic Studies 33.)

Vorster, W S 1977. 'n Ou Boek in 'n nuwe wereld: Gedagtes rondom die interpretasie van die Nuwe Testament. Pretoria: UNISA. (Miscellanea 10.)

Westermann, C 1990. Die Klagelieder: Forschungsgeschichte und Auslegung. Neukirchen-Vluyn: Neukirchener Verlag.

- 1991. Forschungsgeschichte zur Weisheitsliteratuur 1950-1990. Stuttgart: Calwer.

Who was who 1961-1970: A companion to who's who. 1971. London: Adam \& Charles Black. 